\title{
İlkokulda Finansal Okuryazarlık: Demografik Faktörler Finansal Tutum ve Davranışları Farklılaştırıyor mu?
}

\author{
Dr. Öğr. Üyesi Lütfullah ÇELIKKTEN* \\ İstanbul Ayvansaray Üniversitesi, Plato Meslek Yüksekokulu, Çocuk Gelişimi Programı, \\ İstanbul / Türkiye, lutfullah.celikten@gmail.com, ORCID: 0000-0002-5300-9936 \\ Prof. Dr. M. Cihangir DOĞAN \\ Marmara Üniversitesi, Atatürk Eğitim Fakültesi, Temel Eğitim Bölümü, İstanbul / Türkiye, \\ mcdogan@marmara.edu.tr, ORCID: 0000-0003-1473-7866 \\ Meltem DİşLİ ÇELİKTEN \\ Milli Eğitim Bakanlığı, İstanbul / Türkiye, \\ meltemdisli@gmail.com, ORCID: 0000-0001-5473-3048
}

\section{$\ddot{O} z$}

$\mathrm{Bu}$ araştırmada ilkokul 4. sınıf öğrencilerinin finansal okuryazarlık tutum ve davranışlarının farklı değişkenlere göre incelenmesi amaçlanmıştır. Nicel araştırma yönteminin benimsendiği araştırma, tarama modelinde betimsel bir çalışma olarak yürütülmüştür. Araştırmanın katılımcılarını Tokat ili Erbaa ilçesinde öğrenim gören 193 ilkokul 4. sınıf öğrencisi oluşturmaktadır. Araştırmada veri toplama aracı olarak "Marmara Finansal Okuryazarlık Tutum ve Davranış Ölçeği” kullanılmıştır. Araştırma sonuçlarına göre, öğrencilerin finansal okuryazarlık tutum ve davranış düzeylerinin yüksek olduğu tespit edilmiştir. Çeşitli değişkenler açısından gerçekleştirilen incelemelerde ise öğrencilerin finansal okuryazarlık tutum ve davranışlarının "aile türü,

* Sorumlu Yazar. Tel: +90 5445329597

Makale Tarih Bilgisi. Gönderim: 12.05.2021, Kabûl: 14.09.2021, Erken Görünüm: 10.02.2022, Basım: Haziran, 2023

(C) 2023. Kalem Eğitim ve Sağlık Hizmetleri Vakfı. Bütün Hakları Saklıdır. ISSN: 2146-5606, e-ISSN: 2687-6574 
kumbaraya sahip olma durumu, alışverişe gitme sıklığ lık alma sıklığı” değişkenlerine göre istatistikî olarak anlamlı farklılıklar gösterdiği, “cinsiyet, kardeş sayısı ve ailenin ortalama geliri” değişkenlerine göre istatistikî olarak anlamlı farklılıklar göstermediği tespit edilmiştir. Bu sonuçlara göre ilkokul 4 . sınıf öğrencilerinin finansal okuryazarlık tutum ve davranışlarının çeşitli demografik değişkenlerden etkilendiği ve bu değişkenlerin daha çok aile ve ebeveyn tutumuna bağlı faktörler olduğu yargısına ulaşılmıştır.

Anahtar Kelimeler: İlkokul; Finansal okuryazarlık; Finansal bilgi; Finansal tutum; Finansal davranış.

\title{
Financial Literacy in Primary School: Do Demographic Factors Differentiate Financial Attitudes and Behaviors?
}

\begin{abstract}
In this study, it was aimed to examine the financial literacy attitudes and behaviors of primary school $4^{\text {th }}$ grade students according to different variables. The research, in which the quantitative research method was adopted, was carried out as a descriptive study in the scanning model. Participants of the study consist of 193 primary school $4^{\text {th }}$ grade students studying in Erbaa district of Tokat province. "Marmara Financial Literacy Attitude and Behavior Scale" was used as data collection tool in the study. According to the results of the study, it was found that students' financial literacy attitude and behavior levels were high, and they showed statistically significant differences according to the variables of "family type, having a piggy bank, the frequency of going shopping, having pocket money, the frequency of getting pocket money"; It was determined that there was no statistically significant difference according to the variables of "gender, number of siblings and average income of the family". According to these results, it has been concluded that the financial literacy attitudes and behaviors of primary school $4^{\text {th }}$ grade students are affected by various demographic variables and these variables are mostly related to family and parental attitudes.
\end{abstract}

Keywords: Primary school; Financial literacy; Financial knowledge; Financial attitude; Financial behavior.

\section{Extended Summary}

\section{Purpose}

When children become young adults, they are important financial actors whose decisions can influence the society and environment they live in. The fate of societies depends on the attitude and behavior of these actors. For this 
reason, it is frequently stated in the literature that financial literacy should be acquired at an early age (Çarıkçı, 2019; Hapsari, Suryono and Amiliya, 2019; Williams, Morton and Christian, 2020). This idea is based on the idea that financial literacy can shape the financial attitudes and behaviors of children and therefore have positive results on financial decision making in adulthood (Zhu, Yu and Chou, 2021). However, although financial literacy thinking at an early age is based on important evidence, it is seen that these studies are quite limited in both national and international literature (Batty, Collins and Odders-White, 2015; Berry, Karlan and Pradhan, 2018; Çarıkçı, 2019; Çelikten and Doğan, 2020; Hapsari et al., 2019; Puspitarona, Abdulhak and Rusman, 2019; Williams et al., 2020; Yiğitbaş, Temeloğlu and Şimşek, 2020). Based on the limitations in the literature, this study initially focused on primary school students. Secondly, it aimed to examine the financial literacy attitudes and behaviors of these students in terms of various demographic and socio-economic variables.

\section{Method}

The research, in which the quantitative research method was adopted, was carried out as a descriptive study in the scanning model. The participant group of the study consists of 193 primary school $4^{\text {th }}$ grade students studying in the primary schools of the Erbaa district of Tokat. In the research, "Marmara Financial Literacy Attitude and Behavior Scale (MARFÖ)" was used as a data collection tool. The data obtained from the study were analyzed in the IBM Statistical Package for Social Sciences version 22.0 (IBM SPSS Corp; Armonk, NY, USA) package program.

\section{Results and Discussion}

Firstly, the level of students' financial literacy attitude and behavior was determined in the study. According to the results, students' financial literacy attitude and behavior scores were at a "high" level in the whole scale and subdimensions of "need awareness", "financial responsibility", "financial planning and consumption"; In the "spending awareness" and "financial instruments" sub-dimensions, it was found at a "near high" level.

In the study, students' financial literacy attitude and behavior scores were examined in terms of gender variable and it was found that there was no statistically significant difference in the whole scale and its sub-dimensions. This result is in parallel with some studies conducted on secondary school 
students (Ergür-Çengelci, 2019; Ertoğrul, 2020; Gomulia, Barlian, and Dewi, 2020).

In the study, students' financial literacy attitude and behavior scores were examined in terms of the number of siblings variable and it was found that there was no statistically significant difference in the whole scale and its sub-dimensions. According to Van Rooij, Lusardi and Alessie (2011), individuals can be affected by the financial experiences of their siblings. However, according to the results of this study, it can be stated that there is no relationship between the number of siblings and financial literacy attitudes and behaviors.

In the study, students' financial literacy attitude and behavior scores were examined in terms of family type variable. According to the family type variable, the financial literacy attitude and behavior scores of the students showed a statistically significant difference in favor of the students living in the "nuclear family type" in the whole scale and in the "financial responsibility" sub-dimension. Parents' conversations or discussions with their children about financial information, attitudes and behaviors have a strong and lasting effect (Hanson and Olson, 2018).

In the study, it was examined whether the students' financial literacy attitude and behavior scores differ according to the average income of their families. According to the results, it was determined that there was no statistically significant difference between student scores in terms of family income in the whole scale and its sub-dimensions. These results are parallel to some studies conducted on secondary school students (Homan, 2015).

Students' financial literacy attitude and behavior scores were analyzed in terms of having a piggy bank variable. According to the results, the mean scores of the students show a statistically significant difference in favor of the students who have a moneybox in the whole scale and in the "financial responsibility" sub-dimension. According to the Ergür-Çengelci (2019), having a piggy bank causes positive changes in their financial attitudes.

Students' financial literacy attitude and behavior scores were analyzed in terms of the frequency of going shopping variable. According to the results, it was seen that the mean scores of the students showed a statistically significant difference in the "needs awareness" and "financial instruments" sub- 
dimensions and in the whole scale. This difference is in favor of students who say "I often go shopping".

The financial literacy attitude and behavior scores of the students were analyzed in terms of whether they received pocket money from their families. According to the results, it was determined that there is a statistically significant difference in the "financial planning and consumption" and "financial instruments" sub-dimensions and in the whole of the scale, while there is no significant difference in the other sub-dimensions. In the study, students' financial literacy attitude and behavior scores were examined in terms of the frequency of receiving pocket money from their families. According to this variable, it is concluded that there is a significant difference in the "financial planning and consumption" sub-dimension and in the whole scale.

\section{Conclusion}

Finally, in the study, it is seen that the financial literacy attitudes and behaviors of primary school $4^{\text {th }}$ grade students are highly positive, but the financial literacy attitudes and behaviors of the students can be affected by various demographic factors in the context of the variables examined. Among these variables, it is seen that especially the variables of "family type, having a piggy bank, the frequency of going shopping, getting pocket money and the frequency of getting pocket money" affect students' financial attitudes and behaviors. Accordingly, the financial literacy attitudes and behaviors of students living in a nuclear family, who have a piggy bank, who frequently go shopping with their families and who regularly receive pocket money are higher and more positive than other students.

\section{Giriş}

Küreselleşen dünyada endüstriyel yapılardan sosyolojik yapılara kadar birçok alanda değişimler meydana gelmektedir. Yirmi birinci yüzyılda yaşanan bu değişimler çeşitli sorunları da beraberinde getirmektedir. Eğitim bilimi açısından düşünüldüğ̈̈nde, bireylerin okulda öğrendikleri bilgi ve beceriler ile yirmi birinci yüzyılın istediği bilgi ve beceriler arasında uyumsuzluklar ortaya çıkabilmektedir. Çünkü teknolojik ve toplumsal gelişmelerin hızı ile okulların bu gelişmelere uyum sağlama hızı zaman zaman uyuşmamakta ve okullar bu hızın gerisinde kalabilmektedir. Eğitimde politika yapıcılar tarafından çözüm olarak yirmi birinci yüzyılın ihtiyaç duyduğu yetkinlikler belirlenmekte ve bu yetkinlikler eğitim sürecine entegre edilmeye çalışılmaktadır. 
Böylece okullarda teknik becerilerin yanı sıra yaşanan gelişmeler ışığında farklı hayat becerilerine yönelik eğitimler artış göstermektedir.

Günümüzde bireylerin finansal kararlar almasını gerektiren risk faktörlerinin artışı, finansal ürün ve hizmetlerde çeşitlilik ve demografik değişimler gibi gelişmeler söz konusudur. Bu gelişmeler finans dünyasını giderek karmaşıklaştırmakta ve bireylerin vermesi gereken finansal kararların sayısı ve bu kararların önemi artmaktadır (Organisation for Economic Co-operation and Development [OECD], 2020). Ancak son y1llarda yaşanan finansal krizlerin sonuçları bireylerin finans dünyasındaki kararlarının yeterince sağlıklı olmadığını göstermiştir. Özellikle Covid-19 küresel salgını sırasında ortaya çıkan istihdam ve finans sorunları bireylerin finansal başarısızlığına son örneklerinden biri olarak görülmektedir. Bu endişe yaratıcı durum, bireylerin yalnızca hükümet fonlarına ihtiyaç duyduğu anlamının dışında bu sorunların üstesinden gelebileceği becerilere de ihtiyaç duyduklarını göstermektedir. Bu ihtiyaca binaen, son y1llarda finansal ürün ve hizmetleri kullanabilme ve yönetebilme yeteneğini ifade eden finansal okuryazarlık becerisi bütün dünyada kabul gören bir hayat becerisi haline gelmiştir.

\section{Finansal Okuryazarlığa Genel Bir Bakış}

Okuryazarlık, Türkçe sözlükte "okuryazar olma durumu" olarak tanımlanmaktadır. Ancak okuryazarlık üzerine gerçekleştirilen çeşitli tartışmalar, bu tanımın okuryazarlığı sınırladığı ve kavramın daha geniş bilgi ve beceriler ile ilişkili olduğunu vurgulamaktadır (Aşıcı, 2009). Nitekim geçmişte yalnızca kâğıt üzerinde okuma ve yazma yeterliliğine sahip olmak okuryazarlık için yeterli görülebilirken teknolojinin hızla geliştiği bugünlerde okuyabiliyor ve yazabiliyor olmak tek başına okuryazarlığı garanti etmemektedir (Leu, Kinzer, Coiro, Castek ve Henry, 2017). Özellikle "yeni okuryazarlık çalışmaları" ile birlikte günümüzde bilişsel ve dile dayalı iletişim becerilerinin de dâhil olduğu çoğul olguları kapsayan bir terim olarak görülmektedir (Aşıc1, 2009). Gelinen noktada, okuryazarlık farklı alanlara atıfta bulunan türlere ayrılmakta ve Barton ve Hamilton'un (2000, s.7) ifadesiyle "Okuryazarlık uygulamalart insanların okuryazarlıkla yaptı̆̆ şseydir." anlayışı giderek yaygınlaşmaktadır.

Finansal okuryazarlık, günümüzde kabul gören okuryazarlık türlerinden birisidir (OECD, 2020). Basit bir ifadeyle finansal okuryazarlık, finans alanına ait her türlü bilgi, beceri ve tutumun edinilmesi ve bu kazanımların günlük hayata aktarılarak kullanılması ve yönetilmesini ifade etmektedir. Okuryazarlık kavramının deiktik doğasından kaynaklı olarak alanyazında bu 
beceriyi tanımlayan üzerinde uzlaşılmış çerçeve ya da tanım bulunmamaktadır. Golemac ve Lončar'a (2016) göre finansal okuryazarlık tanımları kavramsal ve işlevsel tanımlar olarak iki gruba ayrılmaktadır. Kavramsal tanımlar, içeriği analiz ederek sunan tanımlardır. Kavramsal tanıma Remund'un (2010, s.284): "Bireyin ekonomik şartlarda ve yaşamsal koşullardaki değissimleri dikkate alarak temel finansal kavramları algılama ve açılklama, kısa vadede etkin kararlar alabilme, uzun vadede finansal planlamalar yapabilme yoluyla şahsi finansal durumunu yönetebilme becerisidir." şeklindeki tanımı örnek olarak verilebilir. İşlevsel tanımlar ise finansal okuryazarlığı bütçeleme, tasarruf, yatırım gibi ölçülebilir değişkenlerle tanımlamaktadır. İşlevsel tanıma ise Atkinson ve Messy (2012, s.14) tarafindan yapılan "Doğru finansal kararlar almak ve bireysel refaha ulaşabilmek için gerekli olan farkındalı, bilgi, beceri, tutum ve davranışların bileşimidir." tanımı örnek olabilir. Anlaş1lacağ üzere, finansal okuryazarlık kavramı geniş bir çerçevede ele alınmakta ve tartışı1maktadır.

$\mathrm{Bu}$ araştırmada hem OECD araştırmalarında hem de çeşitli çalışmalarda (Paraboni ve daCosta Jr, 2021; Murarka ve Oates, 2020; Swiecka, Yeşildağ, Özen ve Grima, 2020) kullanılan ve genel olarak kabul gören bir tanım olması sebebiyle Atkinson ve Messy (2012) tarafindan yapılan tanım benimsenmiştir. Bu tanıma göre finansal okuryazarlık; finansal bilgi, tutum ve davranışların bileşimidir. Finansal bilgi, finansal ürün seçimi konusunda ve matematiksel hesaplamalara yardımcı olur ve finansal refahı sağlamaktadır (Lusardi ve Mitchell, 2014). Finansal tutum, bireylerin finansal bilgileri dâhilindeki eğilimleridir. Bireylerin bilgi ve tutumları dâhilindeki eylemleri ise finansal davranışı tanımlamaktadır (OECD, 2012). Finansal okuryazarlığın tanımları her ne kadar çeşitli olsa da alanyazında uzlaşılan şey finansal bilginin tutumlar ve davranışlara yansıması gerektiğidir. Aksi takdirde finansal bilginin varlığ tek başına anlamlı olmayacaktır (Atkinson ve Messy, 2012; Golemac ve Lončar, 2016; Kempson, Perotti ve Scott, 2013). Finansal okuryazarlık bireylere, finansal ürün ve hizmetler konusunda bilgi sağlamakta ve değişen hayat koşullarında kişisel veya aile kaynaklarını verimli bir şekilde yönetebilme firsatı sunmaktadır. Dolayısıyla hükümetler için finansal okuryazarlığın artırılması ile ekonomik krizlerin yönetimi ve etkilerinin azaltılması ya da bireylerin tasarrufa yöneltilmesi ve tasarruflarının ekonomik gelişme için kullanılması gibi iyileşmeler söz konusu olabilir (Atkinson ve Messy, 2013). Bu kazanımları nedeniyle finansal okuryazarlık, bir tür insan sermayesi yatırımı 
(Lusardi, Michaud ve Mitchell, 2017) ya da bir müdahale çalışması (Opletalová, 2015) olarak değerlendirilmektedir.

\section{Araştırmanın Amacı ve Önemi}

Çocuklar, birer genç yetişkin olduklarında kararlarıyla içinde bulundukları toplumu ve çevreyi etkileyebilecek önemli finansal aktörlerdir. Toplumların kaderi, bu aktörlerin tutum ve davranışlarına bağlıdır. Günümüzde çocuklar finansal ürün ve hizmetlerle tahmin edildiğinden daha erken yaşlarda karşılaşabilmektedir (OECD, 2020). Bu sebeple finansal okuryazarlığın erken yaşlarda kazanılması gerektiği literatürde sıklıkla dile getirilmektedir (Çarıkç1, 2019; Hapsari, Suryono ve Amiliya; 2019; Williams, Morton ve Christian, 2020). Bu düşünce finansal okuryazarlığın çocuklarda finansal tutum ve davranışlarını şekillendirebileceği ve dolayısıyla yetişkinlik dönemlerinde finansal karar verme üzerinde olumlu sonuçlar doğuracağ düşüncesine dayanmaktadır (Zhu, Yu ve Chou, 2021). Ayrıca gençler arasındaki finansal okuryazarlık oranının düşük olması finansal okuryazarlığın erken yaşta kazanılmasının önemli dayanaklarından birisidir (Lusardi, 2019).

Erken yaşta finansal okuryazarlık düşüncesinin önemli kanıtlara dayanmasına rağmen hem ulusal hem de uluslararası literatürde bu çalışmaların oldukça sınırlı olduğu görülmektedir (Batty, Collins ve Odders-White, 2015; Berry, Karlan ve Pradhan, 2018; Çarıkçı, 2019; Çelikten ve Doğan, 2020; Hapsari ve ark., 2019; Puspitarona, Abdulhak ve Rusman, 2019; Williams ve ark., 2020; Yiğitbaş, Temeloğlu ve Şimşek, 2020). Alanyazın incelendiğinde finansal okuryazarlık üzerine gerçekleştirilen çalışmaların belirli bazı geleneksel kalıplar etrafında şekillendiği görülmektedir. Özellikle Türkiye örnekleminde olmak üzere ilkokula yönelik finansal okuryazarlık araştırmalarının genellikle bu kalıpların dışında kaldığı görülmektedir. Buna göre araştırmalar çoğunlukla "finansal okuryazarlı̆̆n sonuçlarını analiz etmek, finansal okuryazarlı̆̆ etkileyen faktörleri belirlemek, finansal ĕgitimin finansal okuryazarlığı geliş̧tirme üzerindeki etkisini değerlendirmek ve çeşitli nüfus grupları arasindaki seviyeleri tespit etmek" konularına odaklanmıştır (Goyal ve Kumar, 2021, s.81).

$\mathrm{Bu}$ araştırma, alanyazındaki sınırlılıktan yola çıkarak ilk adımda ilkokul öğrencilerine odaklanmıştır. İkinci olarak ise, bu öğrencilerin finansal okuryazarlık tutum ve davranışlarını çeşitli demografik değişkenler açısından incelemeyi hedeflemiştir. Demografik değişkenler, yetişkin gruplarına odaklanan önceki araştırmalarda finansal okuryazarlığa etkisi kabul edilen faktörler 
olarak görülmektedir (Mahdzan ve Tabiani, 2013; Garg ve Singh, 2018). Finansal okuryazarlığın iki önemli alt boyutu olan finansal tutum ve davranışlar ile onu etkileyen çeşitli demografik faktörler üzerine odaklanan araştırmaların ilkokul seviyesindeki niceliksel eksikliği göz önüne alındığında bu çalışmanın mevcut literatüre iki farklı katkıda bulunacağ 1 düşünülmektedir. Bu katkılardan ilki, ulaşılan literatür bağlamında Türkiye'de çocukların finansal tutum ve davranışlarını inceleyen ilk çalışmalardan birisi olmasıdır. İkinci olarak ise demografik faktörlerin finansal tutum ve davranış üzerindeki etkisine dair yeni kanıtlar sunmasıdır. Araştırmanın ayrıca Türkiye örneklemi üzerinde yürütülecek diğer araştırmalara ve ilkokula yönelik finansal eğitim çalışmalara 1şık tutacağına inanılmaktadır. Araştırmanın amacı doğrultusunda aşağıdaki sorulara yanıt aranmıştır:

1. İlkokul 4. sınıf öğrencilerinin finansal okuryazarlık tutum ve davranışları ne düzeydedir?

2. İlkokul 4. sınıf öğrencilerinin finansal okuryazarlık tutum ve davranışları; cinsiyet, kardeş sayısı, aile türü, ailenin ortalama geliri, kumbaraya sahip olma durumu, alışverişe gitme sıklığ 1 , harçlık alma durumu ve harçlık alma sıklığı değişkenlerine göre istatistiksel olarak anlamlı düzeyde bir farkl1l1k göstermekte midir?

\section{Yöntem}

\section{Araştırma Modeli}

Nicel yaklaşımın temel alındığı bu araştırma, tarama modelinde ve betimsel bir çalışmadır. Tarama modelindeki araştırmalar, bir konu ya da olay hakkında katılımcıların ilgi, tutum, beceri gibi özelliklerinin belirlendiği çalışmalardır (Büyüköztürk, Kılıç-Çakmak, Akgün, Karadeniz ve Demirel, 2013). Bu araştırmada da ilkokul 4. sınıf öğrencilerinin finansal okuryazarlık tutum ve davranışlarının çeşitli değişkenler açısından incelenmesi amaçlanmıştır.

\section{Çalışma Grubu}

Araştırmanın çalışma grubunu, Tokat ili Erbaa ilçesine bağlı ilkokullarda öğrenim gören 193 ilkokul 4. sınıf öğrencisi oluşturmaktadır. Katılımc1ların belirlenmesinde ölçüt örnekleme yöntemi kullanılmıştır. Bu örnekleme türü, önceden kararlaştırılmış kriterleri karşılayan bütün durumların çalışılmasidır (Patton, 2014). Bu kriterler araştırmacılar tarafindan hazırlanabilir veya önceden hazırlanmış bir kriter listesi kullanılabilir (Yıldırım ve Şimşek, 2016). Bu araştırmada kriter "öğrencilerin araştırma öncesi belirli bir finansal 
okuryazarlık eğitimine tabi tutulmamış olmaları" olarak belirlenmiştir. Katılımcılara ilişkin demografik bilgiler Tablo 1'de sunulmuştur:

Tablo 1. Kat1limc1 Gruba Ait Demografik Bilgiler

\begin{tabular}{llll}
\hline Demografik Değişkenler & & f & $\mathbf{\%}$ \\
\hline Cinsiyet & Erkek & 101 & 52.3 \\
& Kadın & 92 & 47.7 \\
\hline Kardeş Sayısı & 1 & 26 & 13.5 \\
& 2 & 80 & 41.5 \\
& 3 & 68 & 35.2 \\
& 4 ve üzeri & 19 & 9.8 \\
\hline Aile Türü & Çekirdek aile & 161 & 83.4 \\
& Geniş aile & 32 & 16.6 \\
\hline Ailenizin aylık ortalama & Asgari ücret (düşük) & 69 & 35.8 \\
geliri nedir? & 3000-6000 arası (orta) & 82 & 42.5 \\
& 6000 ve üzeri (yüksek) & 42 & 21.8 \\
\hline Kendinize ait bir kumbaranız & Kumbaram var & 151 & 78.2 \\
var mı? & Kumbaram yok & 42 & 21.8 \\
\hline Ailenizle birlikte alışverişe & Gitmem & 6 & 3.1 \\
hangi siklıkla gidersiniz? & Bazen giderim & 126 & 65.3 \\
& Siklıkla giderim & 61 & 31.6 \\
\hline Aileniz size harçlık veriyor mu? & Evet & 179 & 92.7 \\
& Hayırr & 14 & 7.3 \\
\hline Ailenizden ne kadar sıklıkla & Harçlı almıyorum & 14 & 7.3 \\
harçlık alıyorsunuz? & Ara sıra alıyorum & 76 & 39.4 \\
& Düzenli alıyorum & 103 & 53.4 \\
\hline Toplam & & $\mathbf{1 9 3}$ & $\mathbf{1 0 0}$ \\
\hline
\end{tabular}

\section{Veri Toplama Araçları}

Araştırmada veri toplama aracı olarak "Marmara Finansal Okuryazarlık Tutum ve Davranış Ölçeği (MARFÖ)" kullanılmıştır. Marmara Finansal Okuryazarlık Tutum ve Davranış Ölçeği, Çelikten ve Doğan (2020) tarafından ilkokul öğrencilerinin finansal okuryazarlık tutum ve davranışlarını tespit etmek amacıyla geliştirilmiştir. Ölçek 21 maddeden oluşan ve en yüksekten en düşüğe "Kesinlikle Katılıyorum, Katılıyorum, Kararsızım, Katılmıyorum, Hiç Katılmıyorum" şeklinde derecelendirilmenin kullanıldığı 5'li likert tipi olarak düzenlenmiştir. Ölçekten alınacak en yüksek puan 105, en düşük puan 21 olarak belirlenmiştir. Ölçek "Finansal Sorumluluk (max:30 puan), Finansal Planlama ve Tüketim (max:25 puan), İhtiyaç Farkındalığ (max:15 puan), Harcama Bilinci (max:15 puan), Finansal Araçlar (max:20 puan)" isimleri verilen beş alt boyuta sahiptir. Ölçeğin Cronbach's Alfa iç tutarlılık katsayısı ölçeğin tamamı için 0.83; Spearman Brown iki yarı test korelasyonu 0.79 olarak 
hesaplanmıştır. Bu araştırma için hesaplanan Cronbach's Alfa iç tutarlılık katsayı1s1 0.70 olarak bulunmuştur.

\section{Veri Toplanması ve Analizi}

Araştırma verileri 2020-2021 eğitim öğretim yılının ikinci döneminde toplanmıştır. Verilerin toplanması öncesi araştırmacılar tarafindan etik ilkelere uygunluk onayı için İstanbul Ayvansaray Üniversitesi Akademik Araştırma ve Yayın Etiği Kuruluna başvurulmuş ve 23.02.2021 tarih ve E31675095-299-2100001393 sayılı onay raporu alınmıştır. Verilerin toplanması esnasında öğrencilere araştırma hakkında bilgi verilmiş, ölçek formunda ilgili yönergelere yer verilmiş ve öğrencilerden samimi cevaplar vermeleri istenmiştir.

Araştırmadan elde edilen veriler IBM Statistical Package for Social Sciences versiyon 22.0 (IBM SPSS Corp; Armonk, NY, USA) paket programına işlenerek analiz edilmiştir. İlk olarak betimleyici istatistikler yapılmış ve verilerin normal dağ 11 ım gösterip göstermediği kontrol edilmiştir. Normallik incelemesinde çarpıklık değeri dikkate alınmaktadır. Büyüköztürk'e (2019) göre çarpıklık katsayısının +1 ile -1 arasında olması normal dağılımı göstermektedir. $\mathrm{Bu}$ araştırmada basıklık ve çarpıklık katsayısının $(\mathrm{BK}=0.212$; $\mathrm{C} K=-$ 0.243 ) normal dağılım için kabul edilebilir değerler arasında olduğu görülmüş ve parametrik testler tercih edilmiştir. Buna göre araştırmada, "cinsiyet, aile türü, kumbaraya sahip olma durumu, alışverişe gitme sıklığı, harçlık alma durumu" değişkenleri için bağımsız gruplar t testi ve "kardeş sayısı, ailenin ortalama geliri, alışverişe gitme sıklığı, harçlık alma sıklığı" değişkenleri için tek yönlü varyans analizi (ANOVA) yapılmıştır.

\section{Sinırlılıklar}

Araştırma; örneklemi itibariyle Tokat ili Erbaa ilçesinde öğrenim görmekte olan ilkokul 4. sınıf öğrencileriyle, veri toplama aracı itibariyle de kullanılan ölçek formuyla sınırlıdır. Alanyazında finansal okuryazarlığın finansal bilgi, finansal tutum ve finansal davranış olmak üzere üç alt boyutu bulunduğu kabul edilmektedir. Bu araştırma amacı doğrultusunda yalnızca finansal tutum ve davranış boyutlarına odaklanmıştır. Bu duruma ek olarak Türkiye örnekleminde ilkokul öğrencileri düzeyinde finansal okuryazarlık araştırmalarının sayısı oldukça sınırlıdır. Dolayısıyla araştırmadan elde edilen veriler sadece bu boyutlarla sınırlı olarak analiz edilmiş ve sınırlı sayıdaki araştırma sonuçları ile karşılaştırılarak yorumlanmıştır. 


\section{Bulgular}

\section{Öğrencilerin Finansal Okuryazarlık Tutum ve Davranışlarına İliş-} kin Bulgular

Araştırmanın birinci alt problemi "İlkokul 4. sınıf öğrencilerinin finansal okuryazarlık tutum ve davranışları ne düzeydedir?” şeklindedir. Öğrencilerin finansal okuryazarlık tutum ve davranış ölçeği puanları "puan ortalaması/madde sayısı" bazında incelendiğinde ölçeğin tamamı için "yüksek $(\overline{\mathrm{x}}=86.06)$ " düzeyde puan aldıkları tespit edilmiştir. Ölçek alt boyutlarında ise ihtiyaç farkındalığ $(\overline{\mathrm{x}}=13.49)$, finansal sorumluluk $(\overline{\mathrm{x}}=25.97)$, finansal planlama ve tüketim $(\bar{x}=20.87)$ boyutlarında "yüksek", harcama bilinci $(\bar{x}=11.91)$ ve finansal araçlar $(\overline{\mathrm{x}}=13.79)$ boyutlarında ise "yükseğe yakın" düzeyde puan aldıkları görülmektedir.

\section{Öğrencilerin Finansal Okuryazarlık Tutum ve Davranışlarının Çe- şitli Değişkenler Açısından İncelenmesine Yönelik Bulgular}

Araştırmanın ikinci alt problemi "İlkokul 4. sınıf öğrencilerinin finansal okuryazarlık tutum ve davranışları; cinsiyet, kardeş sayısı, aile türü, ailenin ortalama geliri, kumbaraya sahip olma durumu, alışverişe gitme sıklığı, harçlık alma durumu ve harçlık alma sıklığı değişkenlerine göre istatistiksel olarak anlamlı düzeyde bir farklılık göstermekte midir?" şeklinde oluşturulmuştur. $\mathrm{Bu}$ alt probleme ilişkin bulgular aşağıda sırasıyla sunulmuştur.

Araştırmada ilk olarak öğrencilerin finansal okuryazarlık tutum ve davranışları ile cinsiyetleri arasında istatistiksel olarak anlamlı bir fark olup olmadığ 1 araştırılmıştır. Bu teste ilişkin bulgular Tablo 2'de yer almaktadır. Tablo 2'de görüldüğü üzere öğrencilerin ölçeğin tümü ve alt boyutlarına ait finansal okuryazarlık tutum ve davranış puanları cinsiyete göre istatistiksel olarak anlamlı bir fark göstermemektedir $(p>0.05)$. 
Tablo 2. Öğrencilerin MARFÖ Puanlarının Cinsiyete Göre Bağımsız t Testi Sonuçları

\begin{tabular}{llllllll}
\hline Ölçek & Cinsiyet & $\mathbf{N}$ & $\overline{\mathbf{X}}$ & $\mathbf{S}$ & $\mathbf{S d}$ & $\mathbf{t}$ & $\boldsymbol{p}$ \\
\hline Finansal & Erkek & 101 & 26.12 & 3.46 & 191 & 0.68 & .49 \\
Sorumluluk & Kadın & 92 & 25.81 & 2.76 & & & \\
\hline Finansal Planlama & Erkek & 101 & 20.52 & 3.30 & 191 & 1.61 & .10 \\
ve Tüketim & Kadın & 92 & 21.26 & 3.06 & & & \\
\hline İhtiyaç & Erkek & 101 & 13.38 & 2.04 & 191 & 0.86 & .39 \\
Farkındalığ1 & Kadın & 92 & 13.61 & 1.52 & & & \\
\hline Harcama Bilinci & Erkek & 101 & 11.65 & 2.75 & 191 & 1.50 & .13 \\
& Kadın & 92 & 12.20 & 2.30 & & & \\
\hline Finansal Araçlar & Erkek & 101 & 13.49 & 3.99 & 191 & 1.17 & .24 \\
& Kadın & 92 & 14.13 & 3.57 & & & \\
\hline Ölçeğin & Erkek & 101 & 85.18 & 8.12 & 191 & 1.53 & .12 \\
Tamamı İçin & Kadın & 92 & 87.03 & 8.70 & & & \\
\hline
\end{tabular}

Araştırmada ikinci olarak öğrencilerin finansal okuryazarlık tutum ve davranışları ile kardeş sayıları arasında istatistiksel olarak anlamlı bir fark olup olmadığı araştırılmıştır. Bu teste ilişkin bulgular Tablo 3'te yer almaktadir.

Tablo 3. Öğrencilerin MARFÖ Puanlarının Kardeş Sayısı Değişkenine Göre Tek Yönlü Anova Testi Sonuçları

\begin{tabular}{|c|c|c|c|c|c|c|}
\hline Ölçek & $\begin{array}{l}\text { Varyansın } \\
\text { Kaynağı }\end{array}$ & $\begin{array}{l}\text { Kareler Top- } \\
\text { lamı }\end{array}$ & Sd & $\begin{array}{l}\text { Kareler Orta- } \\
\text { laması }\end{array}$ & $\mathbf{F}$ & $p$ \\
\hline Finansal & Gruplararas1 & 18.577 & 3 & 6.192 & 0.621 & .602 \\
\hline \multirow[t]{2}{*}{ Sorumluluk } & Gruplariçi & 1884.731 & 189 & 9.972 & & \\
\hline & Toplam & 1903.308 & 192 & & & \\
\hline \multirow{3}{*}{$\begin{array}{l}\text { Finansal } \\
\text { Planlama ve } \\
\text { Tüketim }\end{array}$} & Gruplararas 1 & 27.096 & 3 & 9.032 & 0.879 & .453 \\
\hline & Gruplariçi & 1942.323 & 189 & 10.277 & & \\
\hline & Toplam & 1969.419 & 192 & & & \\
\hline \multirow{3}{*}{$\begin{array}{l}\text { İhtiyaç } \\
\text { Farkındalığ1 }\end{array}$} & Gruplararas & 6.603 & 3 & 2.201 & 0.666 & .574 \\
\hline & Gruplariçi & 624.369 & 189 & 3.304 & & \\
\hline & Toplam & 630.972 & 192 & & & \\
\hline \multirow{3}{*}{$\begin{array}{l}\text { Harcama Bi- } \\
\text { linci }\end{array}$} & Gruplararas1 & 0.504 & 3 & 0.168 & 0.025 & .995 \\
\hline & Gruplariçi & 1258.045 & 189 & 6.656 & & \\
\hline & Toplam & 1258.548 & 192 & & & \\
\hline \multirow{3}{*}{$\begin{array}{l}\text { Finansal } \\
\text { Araçlar }\end{array}$} & Gruplararas1 & 2.810 & 3 & 0.937 & 0.064 & .979 \\
\hline & Gruplariçi & 2776.705 & 189 & 14.692 & & \\
\hline & Toplam & 2779.515 & 192 & & & \\
\hline \multirow{3}{*}{$\begin{array}{l}\text { Ölçeğin Ta- } \\
\text { mamı İçin }\end{array}$} & Gruplararas1 & 42.874 & 3 & 14.291 & 0.199 & .897 \\
\hline & Gruplariçi & 13605.213 & 189 & 71.985 & & \\
\hline & Toplam & 13648.087 & 192 & & & \\
\hline
\end{tabular}

Tablo 3 incelendiğinde öğrencilerin finansal okuryazarlık tutum ve davranış puanları ölçeğin tümü ve alt boyutlarında kardeş sayısı değişkenine göre anlamlı bir fark göstermemektedir $(p>0.05)$. 
Araştırmada üçüncü olarak öğrencilerin finansal okuryazarlık tutum ve davranışları ile aile türü arasında istatistiksel olarak anlamlı bir fark olup olmadığı araştırılmıştır. Bu teste ilişkin bulgular Tablo 4'te yer almaktadır.

Tablo 4. Öğrencilerin MARFÖ Puanlarının Aile Türü Değişkenine Göre Bağımsız $t$ Testi Sonuçları

\begin{tabular}{lllllccc}
\hline Ölçek & Aile Türü & $\mathbf{N}$ & $\overline{\mathbf{X}}$ & $\mathbf{S}$ & $\mathbf{S d}$ & $\mathbf{t}$ & $\boldsymbol{p}$ \\
\hline Finansal & Çekirdek Aile & 161 & 26.29 & 2.93 & 191 & 3.25 & $.001^{*}$ \\
Sorumluluk & Geniş Aile & 32 & 24.36 & 3.69 & & & \\
\hline Finansal Plan- & Çekirdek Aile & 161 & 21.00 & 3.07 & 191 & 1.25 & .211 \\
lama ve Tüketim & Geniş Aile & 32 & 20.22 & 3.75 & & & \\
\hline İhtiyaç & Çekirdek Aile & 161 & 13.54 & 1.76 & 191 & 0.94 & .347 \\
Farkındalı̆̆1 & Geniş Aile & 32 & 13.21 & 2.04 & & & \\
\hline Harcama Bilinci & Çekirdek Aile & 161 & 12.00 & 2.58 & 191 & 1.08 & .279 \\
& Geniş Aile & 32 & 11.46 & 2.39 & & & \\
\hline Finansal Araçlar & Çekirdek Aile & 161 & 13.95 & 3.82 & 191 & 1.30 & .194 \\
& Geniş Aile & 32 & 13.00 & 3.64 & & & \\
\hline Ölçeğin Tamamı & Çekirdek Aile & 161 & 86.81 & 8.06 & 191 & 2.83 & $.005^{*}$ \\
İçin & Geniş Aile & 32 & 82.27 & 9.30 & & & \\
$* 00.05$ & & & & & & &
\end{tabular}

Tablo 4 incelendiğinde öğrencilerin finansal okuryazarlık tutum ve davranış puanları aile türü değiş̧kenine göre ölçeğin tümünde ve "finansal sorumluluk" alt boyutunda çekirdek aileye sahip olan öğrenciler lehine istatistiksel olarak anlamlı bir fark göstermektedir $(p<0.05)$. Ölçeğe ait diğer alt boyutlardan elde edilen puanlar incelendiğinde ise aile türü değişkenine göre istatistiksel olarak anlamlı bir fark bulunmamaktadır $(p>0.05)$.

Araştırmada dördüncü olarak öğrencilerin finansal okuryazarlık tutum ve davranışları ile ailenin ortalama geliri arasında istatistiksel olarak anlamlı bir fark olup olmadığ 1 araştırılmıştır. Bu teste ilişkin bulgular Tablo 5 'te yer almaktadır. Tablo 5 incelendiğinde ölçeğin tümü ve alt boyutlarında öğrencilerin finansal okuryazarlık tutum ve davranış puanları ile ailenin ortalama geliri arasında anlamlı bir fark bulunmamaktadır $(p>0.05)$. 
Tablo 5. Öğrencilerin MARFÖ Puanlarının Ailenin Ortalama Geliri Değişkenine Göre Tek Yönlü Anova Testi Sonuçları

\begin{tabular}{|c|c|c|c|c|c|c|}
\hline Ölçek & $\begin{array}{l}\text { Varyansın } \\
\text { Kaynağı }\end{array}$ & $\begin{array}{l}\text { Kareler } \\
\text { Toplamı }\end{array}$ & Sd & $\begin{array}{l}\text { Kareler } \\
\text { Ortala- } \\
\text { ması }\end{array}$ & $\mathbf{F}$ & $p$ \\
\hline Finansal & Gruplararas1 & 0.739 & 2 & 0.369 & 0.037 & .964 \\
\hline Sorumluluk & $\begin{array}{l}\text { Gruplariçi } \\
\text { Toplam }\end{array}$ & $\begin{array}{l}1902.570 \\
1903.308\end{array}$ & $\begin{array}{l}190 \\
192\end{array}$ & 10.014 & & \\
\hline Finansal & Gruplararas1 & 26.834 & 2 & 13.417 & 1.312 & .272 \\
\hline Planlama ve & Gruplariçi & 1942.584 & 190 & 10.224 & & \\
\hline Tüketim & Toplam & 1969.419 & 192 & & & \\
\hline İhtiyaç & Gruplararas & 12.326 & 2 & 6.163 & 1.893 & .153 \\
\hline Farkındalı̆̆ & $\begin{array}{l}\text { Gruplariçi } \\
\text { Toplam }\end{array}$ & $\begin{array}{l}618.646 \\
630.972\end{array}$ & $\begin{array}{l}190 \\
192\end{array}$ & 3.256 & & \\
\hline $\begin{array}{l}\text { Harcama Bi- } \\
\text { linci }\end{array}$ & $\begin{array}{l}\text { Gruplararas1 } \\
\text { Gruplariçi } \\
\text { Toplam }\end{array}$ & $\begin{array}{l}17.508 \\
1241.040 \\
1258.548 \\
\end{array}$ & $\begin{array}{l}2 \\
190 \\
192 \\
\end{array}$ & $\begin{array}{l}8.754 \\
6.532\end{array}$ & 1.340 & .264 \\
\hline $\begin{array}{l}\text { Finansal } \\
\text { Araçlar }\end{array}$ & $\begin{array}{l}\text { Gruplararas1 } \\
\text { Gruplariçi } \\
\text { Toplam }\end{array}$ & $\begin{array}{l}45.718 \\
2733.797 \\
2779.515 \\
\end{array}$ & $\begin{array}{l}2 \\
190 \\
192 \\
\end{array}$ & $\begin{array}{l}22.859 \\
14.388\end{array}$ & 1.589 & .207 \\
\hline $\begin{array}{l}\text { Ölçeğin } \\
\text { Tamamı İçin }\end{array}$ & $\begin{array}{l}\text { Gruplararas1 } \\
\text { Gruplariçi } \\
\text { Toplam }\end{array}$ & $\begin{array}{l}93.972 \\
13554.115 \\
13648.087\end{array}$ & $\begin{array}{l}2 \\
190 \\
192\end{array}$ & $\begin{array}{l}46.986 \\
71.337\end{array}$ & 0.659 & .519 \\
\hline
\end{tabular}

Araştırmada beşinci analiz olarak öğrencilerin finansal okuryazarlık tutum ve davranışları ile kumbaraya sahip olma değişkenine göre istatistiksel olarak anlamlı bir farklılık olup olmadığı incelenmiştir. Bu analize ilişkin bulgular Tablo 6'da yer almaktadır.

Tablo 6. Öğrencilerin MARFÖ Puanlarının Kumbaraya Sahip Olma Değişkenine Göre Bağımsız t Testi Sonuçları

\begin{tabular}{llllllll}
\hline Ölçek & $\begin{array}{l}\text { Kumbaraya Sa- } \\
\text { hip Olma }\end{array}$ & $\mathbf{N}$ & $\overline{\mathbf{X}}$ & $\mathbf{S}$ & Sd & $\mathbf{T}$ & $\boldsymbol{p}$ \\
\hline Finansal & Kumbaram Var & 151 & 26.03 & 3.18 & 191 & 0.47 & $.001^{*}$ \\
Sorumluluk & Kumbaram Yok & 42 & 25.77 & 3.05 & & & \\
\hline Finansal Plan- & Kumbaram Var & 151 & 21.09 & 2.94 & 191 & 1.84 & .211 \\
lama ve Tüketim & Kumbaram Yok & 42 & 20.07 & 3.92 & & & \\
\hline İhtiyaç & Kumbaram Var & 151 & 13.56 & 1.82 & 191 & 1.02 & .347 \\
Farkındalığ1 & Kumbaram Yok & 42 & 13.24 & 1.76 & & & \\
\hline Harcama & Kumbaram Var & 151 & 11.96 & 2.58 & 191 & 0.44 & .279 \\
Bilinci & Kumbaram Yok & 42 & 11.76 & 2.49 & & & \\
\hline Finansal & Kumbaram Var & 151 & 14.07 & 3.80 & 191 & 1.92 & .194 \\
Araçlar & Kumbaram Yok & 42 & 12.80 & 3.66 & & & \\
\hline Ölçeğin & Kumbaram Var & 151 & 86.73 & 8.35 & 191 & 2.11 & $.036^{*}$ \\
Tamamı İçin & Kumbaram Yok & 42 & 83.65 & 8.35 & & & \\
\hline$p<0.05$ & & & & & & &
\end{tabular}


Tablo 6 incelendiğinde öğrencilerin finansal okuryazarlık tutum ve davranış puanları kumbaraya sahip olma değişkenine göre ölçeğin tümünde ve "finansal sorumluluk" alt boyutunda kumbaraya sahip olma lehine istatistiksel olarak anlamlı bir fark göstermektedir $(p<0.05)$. Diğer alt boyutlara ait puanlar ve analiz sonuçları incelendiğinde ise anlamlı bir fark bulunmadığı görülmektedir $(p>0.05)$.

Araştırmada bir diğer analiz olarak öğrencilerin finansal okuryazarlık tutum ve davranışları ile aileleriyle birlikte alışverişe gitme sıklıkları arasında istatistiksel olarak anlamlı bir farklılık olup olmadığı incelenmiştir. Bu analize ilişkin bulgular Tablo 7'de yer almaktadır.

Tablo 7. Öğrencilerin MARFÖ Puanlarının Alışverişe Gitme Sıklığı Değişkenine Göre Tek Yönlü Anova Testi Sonuçları

\begin{tabular}{|c|c|c|c|c|c|c|}
\hline Ölçek & $\begin{array}{l}\text { Varyansın } \\
\text { Kaynağı }\end{array}$ & $\begin{array}{l}\text { Kareler } \\
\text { Toplamı }\end{array}$ & Sd & $\begin{array}{l}\text { Kareler } \\
\text { Ortala- } \\
\text { ması } \\
\end{array}$ & $\mathbf{F}$ & $p$ \\
\hline Finansal & Gruplararas1 & 0.303 & 2 & 0.152 & 0.015 & .985 \\
\hline Sorumluluk & $\begin{array}{l}\text { Gruplariçi } \\
\text { Toplam }\end{array}$ & $\begin{array}{l}1903.005 \\
1903.308\end{array}$ & $\begin{array}{l}190 \\
192\end{array}$ & 10.016 & & \\
\hline $\begin{array}{l}\text { Finansal } \\
\text { Planlama ve } \\
\text { Tüketim }\end{array}$ & $\begin{array}{l}\text { Gruplararası } \\
\text { Gruplariçi } \\
\text { Toplam }\end{array}$ & $\begin{array}{l}21.367 \\
1948.051 \\
1969.419 \\
\end{array}$ & $\begin{array}{l}2 \\
190 \\
192 \\
\end{array}$ & $\begin{array}{l}10.684 \\
10.253\end{array}$ & 1.042 & .355 \\
\hline $\begin{array}{l}\text { İhtiyaç } \\
\text { Farkındalığı }\end{array}$ & $\begin{array}{l}\text { Gruplararası } \\
\text { Gruplariçi } \\
\text { Toplam }\end{array}$ & $\begin{array}{l}20.616 \\
610.356 \\
630.972 \\
\end{array}$ & $\begin{array}{l}2 \\
190 \\
192 \\
\end{array}$ & $\begin{array}{l}10.308 \\
3.212\end{array}$ & 3.209 & $.043^{*}$ \\
\hline $\begin{array}{l}\text { Harcama Bi- } \\
\text { linci }\end{array}$ & $\begin{array}{l}\text { Gruplararası } \\
\text { Gruplariçi } \\
\text { Toplam }\end{array}$ & $\begin{array}{l}8.094 \\
1250.454 \\
1258.548 \\
\end{array}$ & $\begin{array}{l}2 \\
190 \\
192 \\
\end{array}$ & $\begin{array}{l}4.047 \\
6.581\end{array}$ & 0.615 & .542 \\
\hline $\begin{array}{l}\text { Finansal } \\
\text { Araçlar }\end{array}$ & $\begin{array}{l}\text { Gruplararası } \\
\text { Gruplariçi } \\
\text { Toplam }\end{array}$ & $\begin{array}{l}214.128 \\
2565.387 \\
2779.515 \\
\end{array}$ & $\begin{array}{l}2 \\
190 \\
192 \\
\end{array}$ & $\begin{array}{l}107.064 \\
13.502\end{array}$ & 7.929 & $.000^{*}$ \\
\hline $\begin{array}{l}\text { Ölçeğin } \\
\text { Tamamı İçin }\end{array}$ & $\begin{array}{l}\text { Gruplararası } \\
\text { Gruplariçi } \\
\text { Toplam }\end{array}$ & $\begin{array}{l}522.952 \\
13125.136 \\
13648.087\end{array}$ & $\begin{array}{l}2 \\
190 \\
192\end{array}$ & $\begin{array}{l}261.476 \\
69.080\end{array}$ & 3.785 & $.024^{*}$ \\
\hline
\end{tabular}

Tablo 7 incelendiğinde öğrencilerin finansal okuryazarlık tutum ve davranış puanlanı ile alışverişe gitme sıklığı değişkeni arasında ölçeğin tümü ile "ihtiyaç farkındalığı" ve "finansal araçlar" alt boyutlarında istatistiksel olarak anlamlı bir fark bulunmaktadır $(p<0.05)$. Bu farklılığın hangi gruplar arasında olduğunu tespit etmek amaciyla Tukey HSD çoklu karşılaştırma testi gerçekleştirilmiştir. Test sonuçlarına göre anlamlı farklılıklar; ihtiyaç farkındalığı alt boyutunda "gitmem ile bazen giderim" değişkenleri arasında, finansal araçlar alt boyutunda "gitmem ile bazen giderim ve gitmem ile sikl1kla giderim" 
değişkenleri arasında, ölçeğin tümünde ise "gitmem ile sıklıkla giderim" değişkenleri arasındadır. Ölçeğin finansal sorumluluk, finansal planlama ve tüketim, harcama bilinci alt boyutlarında ise finansal okuryazarlık tutum ve davranış puanları ile alışverişe gitme sıklığı arasında anlamlı bir fark bulunmamaktadır $(p>0.05)$.

Araştırmada öğrencilerin finansal okuryazarlık tutum ve davranışları ile ailelerinden harçlık alıp almamaları arasında istatistiksel olarak anlamlı bir farklılık olup olmadığı incelenmiştir. Bu analize ilişkin bulgular Tablo 8'de yer almaktadır.

Tablo 8. Öğrencilerin MARFÖ Puanlarının Harçlık Alma Durumu Değişkenine Göre Bağımsız t Testi Sonuçları

\begin{tabular}{|c|c|c|c|c|c|c|c|}
\hline Ölçek & $\begin{array}{l}\text { Aileniz size harç- } \\
\text { llk veriyor mu? }\end{array}$ & $\mathbf{N}$ & $\overline{\mathbf{X}}$ & $\mathbf{S}$ & Sd & $\mathbf{t}$ & $p$ \\
\hline \multirow{2}{*}{$\begin{array}{l}\text { Finansal } \\
\text { Sorumluluk }\end{array}$} & Evet & 179 & 26.00 & 3.18 & \multirow[t]{2}{*}{191} & $\begin{array}{l}0.41 \\
3\end{array}$ & \multirow[t]{2}{*}{.680} \\
\hline & Hayır & 14 & 25.64 & 2.64 & & & \\
\hline \multirow{2}{*}{$\begin{array}{l}\text { Finansal Planlama } \\
\text { ve Tüketim }\end{array}$} & Evet & 179 & 21.10 & 3.09 & \multirow[t]{2}{*}{191} & \multirow[t]{2}{*}{$\begin{array}{l}3.68 \\
9\end{array}$} & \multirow[t]{2}{*}{$.000 * *$} \\
\hline & Hayır & 14 & 17.92 & 3.19 & & & \\
\hline \multirow{2}{*}{$\begin{array}{l}\text { İhtiyaç } \\
\text { Farkındalığ } 1\end{array}$} & Evet & 179 & 13.55 & 1.78 & \multirow[t]{2}{*}{191} & \multirow[t]{2}{*}{$\begin{array}{l}1.68 \\
1\end{array}$} & \multirow[t]{2}{*}{.094} \\
\hline & Hayır & 14 & 12.71 & 2.05 & & & \\
\hline \multirow{2}{*}{$\begin{array}{l}\text { Harcama } \\
\text { Bilinci }\end{array}$} & Evet & 179 & 11.89 & 2.56 & \multirow[t]{2}{*}{191} & \multirow[t]{2}{*}{$\begin{array}{l}0.34 \\
1\end{array}$} & \multirow[t]{2}{*}{.733} \\
\hline & Hayır & 14 & 12.14 & 2.59 & & & \\
\hline \multirow{2}{*}{$\begin{array}{l}\text { Finansal } \\
\text { Araçlar }\end{array}$} & Evet & 179 & 13.96 & 3.77 & \multirow[t]{2}{*}{191} & \multirow[t]{2}{*}{$\begin{array}{l}2.20 \\
2\end{array}$} & \multirow[t]{2}{*}{$.029 *$} \\
\hline & Hayır & 14 & 11.66 & 3.71 & & & \\
\hline Ölçeğin & Evet & 179 & 86.53 & 8.24 & 191 & 2.801 & $.006 *$ \\
\hline Tamamı İçin & Hayır & 14 & 80.09 & 8.84 & & & \\
\hline
\end{tabular}

Tablo 8 incelendiğinde öğrencilerin ailelerinden harçlık alıp almama durumları ile finansal okuryazarlık tutum ve davranış puanları arasında "finansal planlama ve tüketim" ve "finansal araçlar" alt boyutlarında ve ölçeğin tümünde istatistiksel olarak anlamlı bir fark tespit edilmiştir $(p<0.05)$. Ölçeğin diğer alt boyutlarında ise harçlık alıp almama değişkenine göre anlamlı bir fark bulunmamaktadir $(p>0.05)$.

Araştırmada son olarak öğrencilerin finansal okuryazarlık tutum ve davranışları ile ailelerinden harçlık alma sıklıkları arasında istatistiksel olarak anlamlı bir farklılık olup olmadığı incelenmiştir. Bu analize ilişkin bulgular Tablo 9'da yer almaktadır. 
Tablo 9. Öğrencilerin MARFÖ Puanlarının Harçlık Alma Sıklığı Değişkenine Göre Tek Yönlü Anova Testi Sonuçları

\begin{tabular}{|c|c|c|c|c|c|c|}
\hline Ölçek & $\begin{array}{l}\text { Varyansın } \\
\text { Kaynağı } \\
\end{array}$ & $\begin{array}{l}\text { Kareler } \\
\text { Toplamı } \\
\end{array}$ & Sd & $\begin{array}{l}\text { Kareler } \\
\text { Ortalaması }\end{array}$ & $\mathbf{F}$ & $p$ \\
\hline Finansal & Gruplararas1 & 3.669 & 2 & 1.834 & 0.183 & .833 \\
\hline \multirow[t]{2}{*}{ Sorumluluk } & Gruplariçi & 1899.639 & 190 & 9.998 & & \\
\hline & Toplam & 1903.308 & 192 & & & \\
\hline Finansal & Gruplararası & 143.931 & 2 & 71.965 & 7.490 & $.001 *$ \\
\hline \multirow{2}{*}{$\begin{array}{l}\text { Planlama } \\
\text { ve Tüketim }\end{array}$} & Gruplariçi & 1825.488 & 190 & 9.608 & & \\
\hline & Toplam & 1969.419 & 192 & & & \\
\hline İhtiyaç & Gruplararası & 11.833 & 2 & 5.916 & 1.816 & .166 \\
\hline \multirow{2}{*}{$\begin{array}{l}\text { Farkında- } \\
\text { lığı }\end{array}$} & Gruplariçi & 619.139 & 190 & 3.259 & & \\
\hline & Toplam & 630.972 & 192 & & & \\
\hline Harcama & Gruplararası & 20.319 & 2 & 10.160 & 1.559 & .213 \\
\hline \multirow[t]{2}{*}{ Bilinci } & Gruplariçi & 1238.229 & 190 & 6.517 & & \\
\hline & Toplam & 1258.548 & 192 & & & \\
\hline Finansal & Gruplararası & 75.361 & 2 & 37.681 & 2.648 & .073 \\
\hline \multirow[t]{2}{*}{ Araçlar } & Gruplariçi & 2704.153 & 190 & 14.232 & & \\
\hline & Toplam & 2779.515 & 192 & & & \\
\hline Ölçeğin & Gruplararası & 654.849 & 2 & 327.424 & 4.788 & $.009 *$ \\
\hline Tamamı & Gruplariçi & 12993.238 & 190 & 68.385 & & \\
\hline İçin & Toplam & 13648.087 & 192 & & & \\
\hline
\end{tabular}

Tablo 9 incelendiğinde öğrencilerin ailelerinden harçlık alma sıklıkları ile finansal okuryazarlık tutum ve davranışları arasında "finansal planlama ve tüketim" alt boyutunda ve ölçeğin tümünde anlamlı bir fark bulunmaktadır $(p<0.05)$. Bu farklılığın hangi gruplar arasında olduğuna ilişkin gerçekleştirilen Tukey HSD testi sonuçlarına göre ise "finnansal planlama ve tüketim" alt boyutunda "Harçlık Almıyorum ile Ara Sıra ve Düzenli Alıyorum" değişkenleri arasında, ölçeğin tümünde ise "Harçlık Almıyorum ve Düzenli Alıyorum" değişkenleri arasında anlamlı farklılıklar bulunmaktadır. Diğer alt boyutlardan elde edilen puanlar ile harçlık alma sıklığı arasındaki analize ilişkin bulgularda ise anlamlı bir farklılı̆̆ın olmadığı görülmektedir $(p>0.05)$.

\section{Sonuç ve Tartışma}

Araştırmada ilkokul 4. sınıf öğrencilerinin finansal okuryazarlık tutum ve davranışları cinsiyet, kardeş sayısı, aile türü, ailenin ortalama geliri, kumbaraya sahip olma durumu, alışverişe gitme sıklığı, harçlık alma durumu ve harçlık alma sıklığı değişkenleri açısından incelenmiştir. Araştırmadan elde edilen sonuçlar aşağıda sırasıyla tartışılmıştır.

Araştırmada ilk olarak öğrencilerin finansal okuryazarlık tutum ve davranışlarının düzeyi tespit edilmiştir. Ulaşılan sonuçlara göre, öğrencilerin 
finansal okuryazarlık tutum ve davranış puanları bütün ölçekte ve "ihtiyaç farkındalığı", "finansal sorumluluk", "finansal planlama ve tüketim” alt boyutlarında "yüksek" düzeyde; "harcama bilinci" ve "finansal araçlar" alt boyutlarında ise "yükseğe yakın" düzeyde tespit edilmiştir. Buna göre, ilkokul 4. sınıf öğrencilerinin finansal okuryazarlık tutum ve davranışlarının genel olarak olumlu olduğu söylenebilir. Alanyazında finansal okuryazarlığa yönelik çalışmalar son yıllarda artmaya başlamış olsa bile bu çalışmaların katılımcı gruplarını genellikle genç yetişkinler ve üzeri yaş grupları oluşturmaktadır (Sarıgül, 2020). Bu araştırmada erken yaş grubunu içeren çalışmaların yeterli seviyede olmaması ve finansal okuryazarlığın yalnızca finansal tutum ve davranış boyutlarına odaklanması finansal okuryazarlık düzeyi ile ilgili çeşitli yorumları ve karşılaştırmaları sınırlı kılmaktadır. Bu sınırlılık doğrultusunda araştırmada ulaşılan sonuçlar değerlendirildiğinde; Ertoğrul (2020) tarafından ortaokul öğrencileri üzerine gerçekleştirilen araştırma ile paralellik gösterdiği ve diğer bazı çalışmaların (Batty, Collins, O'rourke ve Odders-White, 2020; Go, Varcoe, Eng, Pho ve Choi, 2012; Hapsari ve ark., 2019) sonuçlarıyla örtüşmediği görülmektedir. Araştırma sonuçlarındaki bu farklılık çeşitli iç ve dış faktörlerin etkisiyle açıklanabilir. İç faktörler olarak çocukların tutum ve davranışlarını doğrudan etkileyen aile ve akran etkisi, ailenin finansal durumu ve değerleri, çocukların finansal okuryazarlığa dair eğitim geçmişi gibi demografik değişkenler düşünülebilir. Dış faktörler ise araştırmacıların kontrol odağ ile ilgili olabilir. Alanyazında finansal okuryazarlık geniş bir kavramsal çerçevede ele alınmaktadır. Bu eğilim hem finansal okuryazarlığı algılama biçimini farklılaştırmakta ve standart ölçme araçlarının geliştirilmesini zorlaştırmaktadır. İlgili araştırmalardaki örneklem grubu, kullanılan ölçme aracı ve araştırmacıların finansal okuryazarlığı hangi açılardan değerlendirdiği gibi faktörlerin sonuçları etkilemiş olabileceği düşünülmektedir. Bütün bunlarla birlikte geniş kapsamlı araştırma sonuçları bireylerin finansal okuryazarlık seviyesinin orta ya da düşük seviyede olduğunu göstermektedir (OECD, 2016).

Araştırmada çeşitli değişkenler açısından gerçekleştirilen analizlerde ilk olarak cinsiyet değişkeni ele alınmıştır. Bu analizden elde edilen sonuçlara göre, öğrencilerin finansal okuryazarlık tutum ve davranış puanlarının cinsiyete göre anlamlı bir fark göstermediği tespit edilmiştir. Bu sonuç, ortaokul öğrencileri üzerine gerçekleştirilen bazı çalışmalar ile paralellik göstermektedir (Ergür-Çengelci, 2019; Ertoğrul, 2020; Gomulia, Barlian ve Dewi, 2020). Buna göre cinsiyet ile finansal okuryazarlık arasında bir ilişki bulunmadığı ifade edilebilir. Elde edilen bu sonuç, ilkokul düzeyindeki öğrencilerin 
cinsiyetleri farketmeksizin finansal konularda ailelerinin kontrolü altında bulundukları ve finansal eylemlerinde henüz özgür olmamaları ile açıklanabilir. Ancak alanyazında bu araştırmadan farklı olarak cinsiyetin finansal okuryazarlık üzerinde etkisi bulunduğunu gösteren çalışmalar bulunmaktadır (Ergüt, Camkıran ve Çilingirtürk, 2020; Sumer ve Gövdeli, 2020; Yiğitbaş ve ark., 2020). Bu sebeple finansal okuryazarlık için cinsiyet değişkeninin daha fazla araştırmaya ihtiyaç duyduğu düşünülebilir. Araştırmada ayrıca "finansal sorumluluk" alt boyutu hariç olmak üzere ölçeğin tümünde kadınların erkeklerden daha fazla puan ortalamasına sahip oldukları görülmektedir. Alanyazında genellikle kadınların erkeklerden daha düşük finansal okuryazarlığa sahip olduğu görüşü hâkimdir (OECD, 2016). Ancak Yiğitbaş ve arkadaşları (2020) finansal okuryazarlık puanlarında; Agarwalla, Barua, Jacob ve Varma (2015) ise yalnızca finansal tutum boyutunda kadınların erkeklere göre daha yüksek puana sahip oldukları sonucuna ulaşmışlardır. Bu sonuç, öğrencilerin yaşamakta olduğu bölgenin sosyo-ekonomik yapısı ile ilişkilendirilebilir. Araştırmanın örneklem grubunu kırsalda yaşayan ve sosyo-ekonomik açıdan orta seviyede yer alan öğrenciler oluşturmaktadır. Kırsalda kadınların iş hayatına katılımı ve girişimci davranışlar gösterme eğilimleri genel olarak yeterli seviyede değildir (Bozdemir, Gülçubuk ve Bayramoğlu, 2021). Ayrıca bu bölgelerde kadınların finansal okuryazarlık oranı diğer bölgelerdeki kadınlardan nispeten daha düşüktür (Karakurum-Özdemir, Kökkızıl ve Uysal, 2019). Bu durum kadınları finansal konularda daha çekingen yaparken ters ilişkili olarak daha fazla tutumlu olma, tüketici davranışlarında daha dikkatli olma gibi finansal tutum ve davranışları artırmış olabilir. Ebeveyn etkisine bağlı olarak bu durum kadın öğrenciler tarafından daha fazla benimsenmiş olabilir. Yine de sonuçlara göre cinsiyetler arasındaki puanların istatistiksel olarak bir farklılaşmadığı gözardı edilmemelidir.

Araştırmada öğrencilerin finansal okuryazarlık tutum ve davranış puanları, kardeş sayısı değişkeni açısından incelenmiş ve ölçeğin tümü ve alt boyutlarında istatistiksel olarak anlamlı bir fark bulunmadığ görülmüştür. Van Rooij, Lusardi ve Alessie'ye (2011) göre bireyler kardeşlerinin finansal deneyimlerinden etkilenebilmektedir. Ancak bu araştırma sonuçlarına göre, kardeş sayısı ile finansal okuryazarlık tutum ve davranışları arasında bir ilişki bulunmadığı ifade edilebilir. Araştırmada kardeş sayısına ek olarak öğrencilerin sahip olduğu aile türü de bir değişken olarak ele alınmıştır. Elde edilen sonuçlara göre öğrencilerin finansal okuryazarlık tutum ve davranış puanlarının aile türü değişkenine göre ölçeğin tümünde ve "finansal sorumluluk" alt 
boyutunda çekirdek aileye sahip olan öğrenciler lehine istatistiksel olarak anlamlı bir fark gösterdiği görülmüştür. Ayrıca öğrencilerin toplam puan ortalamaları genel olarak incelendiğinde çekirdek aileye sahip olan öğrencilerin ortalama puanlarının diğer öğrencilerden yüksek olduğu tespit edilmiştir. İlgili sonuçlar çeşitli görüşler bağlamında değerlendirilebilir. Buna göre ilk olarak ailenin ve ebeveynlerin bireylerin finansal okuryazarlıkları üzerinde etkisi "ebeveynin çocuk üzerindeki etkisi, çocuğun ebeveyn üzerindeki etkisi, eşin eş üzerindeki etkisi ve kardeşin kardeşler üzerindeki etkisi" olarak dört faktörde ele alınmalıdır (Lucey, 2002). İkinci görüş olarak ebeveynlerin çocuklarıyla finansal bilgi, tutum ve davranışlar üzerindeki konuşmaları ya da tartışmalarının güçlü ve kalıcı bir etkisi olduğudur (Hanson ve Olson, 2018). Üçüncü olarak ise aile üyelerinin önceki finansal deneyimleri, diğer üyelerin finansal tutum ve davranışlarına etkide bulunmaktadır. Örneğin, düşük finansal okuryazarlığa sahip aile bireylerinin çocukları ya da kardeşleri daha yüksek finansal okuryazarlığa sahip olabilmektedir (Van Rooij ve ark., 2011). Bu görüşler araştırma sonuçlarıyla birlikte değerlendirildiğinde kardeş sayısına bağlı olmaksızın yani kardeşin kardeş üzerindeki etkisinden bağımsız olarak çekirdek ailelerde en çok finansal sorumluluk boyutunda olmak üzere çocukların finansal tutum ve davranışlarının etkilenme ihtimalinin olabileceğini düşündürmektedir. Ancak bu araştırmada özellikle aile içerisindeki finansal sosyalizasyon bağlamında yani çocukların dâhil olduğu sohbet ya da tartışmalarda finansal konuların ne kadar açık bir şekilde gündeme getirildiği hususunda ek kanıtlara ihtiyaç duyulmaktadır. Bu ebeveynin çocuk üzerindeki ya da çocuğun ebeveyn üzerindeki etkisi hakkında da ek uygulamaların gerekliliğini göstermektedir.

Araştırmada bir diğer analiz olarak öğrencilerin finansal okuryazarlık tutum ve davranış puanları ailelerinin ortalama gelirine göre farklılık gösterip göstermediği incelenmiştir. Bu analizlerden ulaşılan sonuçlara göre, ölçeğin tümü ve alt boyutlarında ailenin ortalama geliri açısından öğrenci puanları arasında istatistiksel olarak anlamlı bir fark bulunmadığ tespit edilmiştir. Buna göre ailelerin aylık ortalama gelirinin finansal okuryazarlık tutum ve davranışları üzerinde etkili olmadığı söylenebilir. Bu sonuçlar ortaokul öğrencileri üzerine gerçekleştirilen bazı çalışmalar ile paralellik göstermektedir (ErgürÇengelci, 2019; Homan, 2015). Buna ek olarak Ertoğrul (2020) gerçekleştirdiği çalışmada finansal okuryazarlık düzeyi ile aile geliri arasında yüksek gelire sahip olan öğrencilerin finansal okuryazarlık puanlarının yüksek olduğunu tespit etmiştir. Ancak yazara göre, finansal davranış boyutunda öğrenci 
puanları aile geliri değişkeni açısından farklılık göstermemiştir. Karaaslan (2020) ise finansal bilgi boyutunda aile geliri ile öğrenci puanları arasında ilişki olduğunu tespit etmiştir. Farklı yaş grupları açısından sonuçlar değerlendirildiğinde ise genellikle gelir ile finansal okuryazarlık arasında ilişki bulunduğu ve yüksek gelire sahip bireylerin daha yüksek finansal okuryazarlığa sahip olduğu ifade edilmektedir (Atkinson ve Messy, 2012; Jariwala, 2013; Kutlu, 2018). Ancak bu sonuçlar daha çok finansal bilgi boyutu ile ilişkilendirilmiştir. Nitekim Kadoya ve Khan (2020) ailelerin geliri ile finansal bilgi boyutu arasında ilişki olduğunu tespit ederken finansal tutum ve davranışlar ile ilişki tespit edememiştir. Farklı araştırmalarla karşılaştırıldığında bu araştırma için ulaşılan sonuçlar ebeveynlerin hane halkı içerisinde gelir-gider dağılımlarının dengesini nasıl kurduğu, harcama ve tüketim alışkanlıkları, çocuklarına harçlık verme isteği gibi durumların etkisiyle açıklanabilir. Örneklem grubu incelendiğinde öğrencilerin tamamına yakını düzenli olarak harçlık almakta ve benzer gelir grubuna ait ailelerde yaşamaktadırlar. Bu durumun bir sonucu olarak öğrenci puanları ailenin ortalama gelirine göre farkl11ık göstermemiş olabilir.

Öğrencilerin finansal okuryazarlık tutum ve davranış puanlarının kumbaraya sahip olma değişkeni açısından incelenmesi sonucunda ise, öğrencilerin toplam puan ortalamalarının ölçeğin tümünde ve "finansal sorumluluk" alt boyutunda kumbaraya sahip olma lehine istatistiksel olarak anlamlı bir fark gösterdiği tespit edilmiştir. Diğer alt boyutlara ait puanlar ve analiz sonuçları incelendiğinde ise anlamlı bir fark bulunmadığı görülmüsstür. Ayrıca öğrencilerin toplam puan ortalamaları ölçeğin tümü için değerlendirildiğinde kumbaraya sahip olan öğrencilerin puanlarının daha yüksek olduğu görülmektedir. Bunlara ek olarak katılımcıların büyük çoğunluğu kumbaraya sahiptir ve finansal tutum ve davranış puanları genel olarak yüksektir. Buna göre, erken yaşta kumbaraya sahip olmanın finansal tutum ve davranışları olumlu yönde değiştirme etkisine sahip olduğu yorumunda bulunulabilir. Alanyazında yer alan çalışmalarda birikim ve tasarruf davranışları ile finansal okuryazarlık arasında pozitif yönlü bir ilişki bulunduğu görülmektedir (Supanantaroek, Lensink ve Hansen, 2017). Bu araştırmadaki ilk değerlendirmelere göre sonuçların Ergür-Çengelci (2019) tarafından gerçekleştirilen çalışma ile örtüştüğü görülmektedir. Araştırmacıya göre öğrencilerin kumbaraya sahip olması onların finansal tutumlarında olumlu değişikliğe neden olmaktadır. Karaaslan'a (2020) göre ortaokul öğrencilerinin kumbara kullanma durumları ile finansal bilgi testi puanları arasında bir ilişki bulunmamaktadır. Araştırma sonuçları 
genel olarak değerlendirildiğinde sonuçların literatürle paralellik gösterdiği ifade edilebilir. Ancak yine de kumbaraya sahip olma değişkeninin ölçeğin diğer alt boyutları ile ilişkisi göz önünde bulundurulduğunda sonuçlar hakkında genel bir yargıda bulunulamamaktadır.

Öğrencilerin finansal okuryazarlık tutum ve davranış puanları alışverişe gitme sıklığı değişkeni açısından incelendiğinde ölçeğin tümü ile "ihtiyaç farkındalı̆̆g" ve "finansal araçlar" alt boyutlarında istatistiksel olarak anlamlı bir fark bulunduğu sonucuna ulaşılmıştır. Bu farklılı̆̆ın hangi gruplar arasında olduğunu tespit etmek amacıyla gerçekleştirilen test sonuçlarına göre anlamlı farklılıkların ihtiyaç farkındalığı alt boyutunda "gitmem ile bazen giderim" değişkenleri arasında, finansal araçlar alt boyutunda "gitmem ile bazen giderim ve gitmem ile sıklıkla giderim" değişkenleri arasında, ölçeğin tümünde ise "gitmem ile sıklıkla giderim" değişkenleri arasında olduğu görülmüştür. Buna göre, çocukluk dönemlerinde aileleriyle birlikte alışverişe gitmenin finansal tutum ve davranışları olumlu şekilde etkilediği söylenebilir. Ayrıca alışverişe gitmenin, çocuklarda "istek ve ihtiyaçlarının ayrımını yapabilme", "para, banka/kredi kartı, ödeme çeki gibi çeşitli finansal araçların doğru ve verimli bir şekilde kullanımı" gibi tutum ve davranışların kazanımında etkili olduğu ifade edilebilir. Ölçeğin finansal sorumluluk, finansal planlama ve tüketim, harcama bilinci alt boyutlarında ise anlamlı bir farklılık bulunmamaktadır. Ergür-Çengelci (2019) tarafından gerçekleştirilen çalışmada alışverişe gitme sıklığının finansal tutum üzerinde bir etkisi bulunmadığı ifade edilmektedir. Elde edilen bu sonuç aileleriyle birlikte alışverişe giden öğrencilerin ebeveynlerinin alışveriş esnasındaki tutum ve davranışlarını gözlemleyebilme ve değerlendirme imkânı bulmaları ile açıklanabilir. Finansal sorumluluk, finansal planlama ve tüketim, harcama bilinci gibi alt boyutlara yönelik sonuçlar ise öğrencilerin alışverişlerinde bağımsız olmamalarından kaynaklı olabilir.

Öğrencilerin finansal okuryazarlık tutum ve davranış puanları ailelerinden harçlık alıp almama durumları açısından incelendiğinde ise "finansal planlama ve tüketim" ve "finansal araçlar" alt boyutlarında ve ölçeğin tümünde istatistiksel olarak anlamlı bir fark olduğu, diğer alt boyutlarda ise anlamlı bir farklılık olmadığı sonucuna ulaşılmıştır. Ayrıca araştırmada diğer bir değişken olarak öğrencilerin ailelerinden harçlık alma sıklıkları incelenmiştir. $\mathrm{Bu}$ değişkene göre ise, "finansal planlama ve tüketim" alt boyutunda ve ölçeğin tümünde anlamlı bir fark olduğu sonucuna ulaşılmıştır. bu farklılıkların "finansal planlama ve tüketim" alt boyutunda "harçlık almıyorum ile ara sıra 
ve düzenli alıyorum" değişkenleri arasında, ölçeğin tümünde ise "harçlık almıyorum ve düzenli alıyorum" değişkenleri arasında olduğu görülmektedir. Buna göre, düzenli olarak harçlık alan öğrencilerin harçlık almayanlara göre daha fazla olumlu tutuma sahip oldukları söylenebilir. Ayrıca düzenli olarak harçlığa sahip olmanın, erken yaşta bütçe oluşturma, harcama, istek ve ihtiyaçların ayrımı ve planlamaların gerçekleştirilmesi gibi finansal planlama boyutu içerisinde değerlendirilebilecek tutum ve davranışların oluşmasına olumlu yönde etkide bulunduğu yorumunda bulunulabilir. Bunlara ek olarak harçlık alan çocuklarda başta para olmak üzere çeşitli finansal araçların doğru kullanımına ve buna bağlı olarak birey için faydalı ve doğru tüketim alışkanlıklarının ortaya çıkabileceği düşünülebilir.

Nihai olarak araştırmada ilkokul 4. sınıf öğrencilerinin finansal okuryazarlık tutum ve davranışlarının yüksek düzeyde olumlu olduğu ancak öğrencilerin finansal okuryazarlık tutum ve davranışlarının ise incelenen değişkenler bağlamında çeşitli demografik faktörlerden etkilenebildiği görülmektedir. Bu değişkenler arasında özellikle "aile türü, kumbaraya sahip olma, alışverişe gitme sıklığı, harçlık alma durumu ve harçlık alma sıklığı" değişkenlerinin öğrencilerin finansal tutum ve davranışları etkilediği görülmektedir. Buna göre, çekirdek ailede yaşayan, kumbarası olan, ailesiyle birlikte sıklıkla alışverişe giden, düzenli olarak harçlık alan öğrencilerin finansal okuryazarlık tutum ve davranışları diğer öğrencilerden daha yüksek ve olumludur. İlgili değişkenler incelendiğinde özellikle aileye bağli faktörlerin finansal tutum ve davranışlarda önemli bir yere sahip olduğu görülmektedir. Buna göre, finansal okuryazarlıkta ebeveyn tutumu başta olmak üzere aileye bağlı olarak değişebilen faktörlerin finansal tutum ve davranışları etkilediği yargısına ulaşılabilir.

\section{Öneriler}

Araştırmada ulaşılan sonuçlar öğrencilerin finansal tutum ve davranışlarında ebeveyn ve akran etkisinin önemini ortaya koymaktadır. Bu faktörlerin etkisi göz önünde bulundurulduğunda ebeveynlerin finansal okuryazarlık konusunda mevcut durumlarının tespiti ve elde edilen sonuçlara göre düzelticiönleyici faaliyetlerin gerçekleştirilmesi gerektiği önerilmektedir. Özellikle ebeveyn-çocuk ilişkisi bağlamında finansal okuryazarlığa yönelik araştırmaların gerçekleștirilmesinin gelecek araştırmalara ya da yeni politikaların oluşturulmasına katkı sağlayacağı düşünülmektedir. Araştırmada kullanılan ölçme aracı yalnızca finansal tutum ve davranışlara odaklanmıştır. Araştırmadan ulaşılan bazı sonuçların değerlendirilmesinde finansal bilginin düzeyinin ne 
olduğuna dair bir takım verileri gerekli kılmaktadır. Dolayısıyla ilkokul düzeyinde gerçekleştirilen çalışmaların Türkiye örnekleminde sayısının yetersiz oluşu araştırma sonuçlarının karşılaştırılmasını önemli derecede sınırlamaktadır. $\mathrm{Bu}$ doğrultuda temel eğitim seviyesinde finansal okuryazarlık becerisine yönelik araştırmaların artırılması önerilmektedir.

\section{Kaynakça}

Agarwalla, S. K., Barua, S. K., Jacob, J. ve Varma, J. R. (2015). Financial literacy among working young in urban India. World Development, 67, 101-109. Doi: 10.1016/j.worlddev.2014.10.004

Aşıcı, M. (2009). Kişisel ve sosyal bir değer olarak okuryazarlık. Değerler Eğitimi Dergisi, 7(17), 9-26. https://ded.dem.org.tr/gorsel/pdf/ded-17-makale-1.pdf

Atkinson, A. ve Messy, F. A. (2012). Measuring financial literacy: Results of the OECD / International Network on Financial Education (INFE) pilot study. https://www.oecd-ilibrary.org/docserver/5k9csfs90fr4-en.pdf_

Barton, D. ve Hamilton, M. (2000). Introduction: exploring situated literacies. D. Barton, M. Hamilton ve R. Ivanic, (Ed.), Situated literacies: reading and writing in context içinde (7-15). London: Routledge.

Batty, M., Collins, J. M., O'Rourke, C. ve Odders-White, E. (2020). Experiential financial education: A field study of my classroom economy in elementary schools. Economics of Education Review, 78,1-11.

Batty, M., Collins, J. M. ve Odders White, E. (2015). Experimental evidence on the effects of financial education on elementary school students' knowledge, behavior, and attitudes. Journal of Consumer Affairs, 49(1), 69-96.

Doi: $10.1111 /$ joca. 12058

Berry, J., Karlan, D. ve Pradhan, M. (2018). The impact of financial education for youth in Ghana. World Development, 102, 71-89.

Doi: 10.1016/j.worlddev.2017.09.011

Bozdemir, M., Gülçubuk, B. ve Bayramoğlu, Z. (2021). Kırsal alandaki kadınların girişimci niteliklerinin ve girişimcilik becerilerinin belirlenmesi: Konya ili araştırması. Trakya Üniversitesi Sosyal Bilimler Dergisi, 23, 87-106.

Doi: 10.26468/trakyasobed.871643

Büyüköztürk, Ş. (2019). Sosyal bilimler için veri analizi el kitabı. Ankara: Pegem A Yayıncilik.

Büyüköztürk, Ş., Kılıç-Çakmak, E., Akgün, Ö. E., Karadeniz, Ş. ve Demirel, F. (2013). Bilimsel araştırma yöntemleri. Ankara: Pegem A Yayıncılık.

Çarıkçı, O. (2019). İlkokul dördüncü sınıf öğrencilerinin finansal farkındalık düzeyinin belirlenmesine yönelik bir araştırma. Akdeniz Üniversitesi Sosyal Bilimler Enstitüsü Dergisi, 5, 133-157. https://dergipark.org.tr/en/pub/aksos/issue/46882/551019_

Çelikten, L. ve Doğan, M. C. (2020). Marmara Finansal Okuryazarlık Tutum ve Davranış Ölçeği'nin geliştirilmesi. HAYEF: Journal of Education, 17(2), 199-221. 
Ergür-Çengelci, Ş. (2019). Ortaokul öğrencilerinin finansal tutumlarının çeşitli değişkenler açısından incelenmesi. Yayımlanmamış yüksek lisans tezi, Gazi Üniversitesi Eğitim Bilimleri Enstitüsü.

Ergüt, Ö., Camkıran, C. ve Çilingirtürk, A. M. (2020). Finansal okuryazarlık düzeyi ile sosyal ağların etkileşimi üzerine ampirik bir uygulama. Manisa Celal Bayar Üniversitesi Sosyal Bilimler Dergisi, 18(Özel Say1), 295-307.

Doi: 10.18026/cbayarsos.635429

Ertoğrul, D. (2020). Ortaokul ögrencilerinin finansal okuryazarlık düzeyleri ve bu düzeyleri etkileyen demografik faktörler. Yayımlanmamış yüksek lisans tezi, Muğla Sitkı Koçman Üniversitesi Eğitim Bilimleri Enstitüsü.

Garg, N. ve Singh, S. (2018). Financial literacy among youth. International Journal of Social Economics, 45(1), 173-186.

Doi: 10.1108/IJSE-11-2016-0303

Go, C. G., Varcoe, K., Eng, T., Pho, W. ve Choi, L. (2012). Money savvy youth: Evaluating the effectiveness of financial education for fourth and fifth graders. https://www.frbsf.org/community-development/files/wp2012-02.pdf

Golemac, Z. ve Lončar, I. (2016). The Importance of financial literacy for teens. Some Studies of Economics Changes, International Research Institute, 27(2), 91-97.

Gomulia, B., Barlian, I. ve Dewi, V. I. (2020). Financial literacy for elementary school students in urban area. Frontiers Journal of Accounting and Business Research, 2(1), 1-9.

Goyal, K. ve Kumar, S. (2021). Financial literacy: A systematic review and bibliometric analysis. International Journal of Consumer Studies, 45, 80-105.

Doi: https://doi.org/10.1111/ijcs.12605

Hanson, A. T. ve Olson, P. M. (2018). Financial literacy and family communication patterns. Journal of Behavioral and Experimental Finance, 19, 64-71.

Hapsari, D. T., Suryono, Y. ve Amiliya, R. (2019). $21^{\text {st }}$ century skills; The effect of Project Based Learning to financial literacy on children aged 5-6 years. Educational Administration Research and Review, 3(2), 85-93.

Homan, H. S. (2015). Comparative study of students financial literacy and its demographic factors. International Conference on Economics and Banking içinde (106-111). Doi: 10.2991/iceb-15.2015.16

Jariwala, H. (2013). To study the level of financial literacy and its impact on investment decision- an in-depth analysis of investors in Gujarat state. Yayımlanmamış doktora tezi, V.M. Patel Institute of Management Ganpat University.

Kadoya, Y. ve Khan, M. S. R. (2020). Financial literacy in Japan: New evidence using financial knowledge, behavior and attitude. Sustainability, 12(9), 1-15. Doi: $10.3390 / \mathrm{su} 12093683$

Karaaslan, H. (2020). Ortaokul öğrencilerinin finansal okuryazarlık düzeylerinin belirlenmesi. Yayımlanmamış yüksek lisans tezi, Gazi Üniversitesi Eğitim Bilimleri Enstitüsü.

Karakurum-Özdemir, K., Kokkizil, M. ve Uysal, G. (2019). Financial literacy in developing countries. Social Indicators Research, 143, 325-353.

Doi: $10.1007 / \mathrm{s} 11205-018-1952-\mathrm{x}$

Kempson, E., Perotti, V. ve Scott, K. (2013). Measuring financial capability: A new instrument and results from low- and middle-income countries. https://openknowledge.worldbank.org/handle/10986/16296 
Kutlu, E. (2018). Üniversite ögrencilerinin finansal okuryazarlı̆̆l: Balıkesir Üniversitesi örneği. Yayımlanmamış doktora tezi, Balıkesir Üniversitesi Sosyal Bilimler Enstitüsü.

Leu, D. J., Kinzer, C. K., Coiro, J., Castek, J. ve Henry, L. A. (2013). New literacies: A dual-level theory of the changing nature of literacy, instruction, and assessment. D. E. Alvermann, N. J. Unrau ve R. B. Ruddell, (Ed.), Theoretical models and processes of reading (6. bask1) içinde (1150-1181). Newark, DE: International Reading Association.

Lucey, T. A. (2002). The personal financial literacy of fourth grade students. Yayımlanmamış yüksek lisans tezi, University of Memphis, TN.

Lusardi, A. (2019). Financial literacy and the need for financial education: evidence and implications. Swiss Journal of Economics and Statistics, 155(1), 1-8.

Lusardi, A., Michaud, P. C. ve Mitchell, O. S. (2017). Optimal financial knowledge and wealth inequiality. Journal of Political Economy, 125(2), 1-48.

Doi: $10.1086 / 690950$

Lusardi, A. ve Mitchell, O. S. (2014). The economic importance of financial literacy: Theory and evidence. Journal of Economic Literature, 52(1), 5-44.

Doi: $10.1257 /$ jel.52.1.5

Mahdzan, N. S. ve Tabiani, S. (2013). The impact of financial literacy on individual saving: An exploratory study in the Malaysian context. Transformation in Business and Economic, 12(1), 41-55.

http://www.transformations.knf.vu.1t/28/se28.pdf

Murarka, L. ve Oates, K. K. (2020). Financial literacy in millennials. Journal of Humanities and Social Sciences Studies, 2(6), 41-54.

Doi: $10.32996 /$ jhsss.2020.2.6.5

Opletalová, A. (2015). Financial education and financial literacy in the Czech education system. Procedia-Social and Behavioral Sciences, 171, 1176-1184.

Doi: 10.1016/j.sbspro.2015.01.229

Organisation for Economic Co-operation and Development (OECD). (2012). Financial education in schools.

https://www.oecd.org/daf/fin/financialeducation/2012\%20Schools\%20Guidelines.pdf

Organisation for Economic Co-operation and Development (OECD). (2016). OECD/INFE international survey of adult financial literacy competencies, OECD. www.oecd.org/finance/OECD-INFE-International-Survey-of-AdultFinancial-Literacy-Competencies.pdf

Organisation for Economic Co-operation and Development (OECD). (2020). PISA 2018 PISA 2018 assessment and analytical framework.

Doi: $10.1787 / 19963777$

Paraboni, A. L. ve da Costa Jr, N. (2021). Improving the level of financial literacy and the influence of the cognitive ability in this process. Journal of Behavioral and Experimental Economics, 90, 1-11.

Doi: $10.1016 /$ j.socec.2020.101656

Patton, M. Q. (2014). Nitel araştırma ve değerlendirme yöntemleri. (M. Bütün ve S. B. Demir, Çev.). Ankara: Pegem Akademi. (Orijinal çalışma basım tarihi 2001.) 
Puspitarona, D. S., Abdulhak, I. ve Rusman, R. (2019). Financial literacy for elementary school students: Case study of Bandung City, Indonesia. International Journal of Learning, Teaching and Educational Research, 18(10), 292-307.

Doi: $10.26803 /$ ijlter.18.10.19

Remund, D. L. (2010). Financial literacy explicated: The case for a clearer definition in an increasingly complex economy. Journal of Consumer Affairs, 44(2), 276-295.

Doi: $10.1111 / \mathrm{j} .1745-6606.2010 .01169 . \mathrm{x}$

Sarıgül, H. (2020). Türkiye'de finansal okuryazarlık alanında yazılan lisansüstü tezlerin içerik analizi. Yüksekögretim ve Bilim Dergisi, 10(1), 153-165.

Doi: $10.5961 /$ jhes. 2020.377

Sumer, S. ve Gövdeli, T. (2020). Finansal okuryazarlık ve finansal davranış üzerine bir çalışma. Oltu Beşeri ve Sosyal Bilimler Fakültesi Dergisi, 1(1), 86-98. https://dergipark.org.tr/en/download/article-file/1162689

Supanantaroek, S., Lensink, R. ve Hansen, N. (2017). The impact of social and financial education on savings attitudes and behavior among primary school children in Uganda. Evaluation Review, 41(6), 511-541.

Doi: 10.1177/0193841X16665719

Swiecka, B., Yeşildağ, E., Özen, E. ve Grima, S. (2020). Financial literacy: The case of Poland. Sustainability, 12(2), 1-17. Doi: 10.3390/su12020700

Van Rooij, M., Lusardi, A. ve Alessie, R. (2011). Financial literacy and stock market participation. Journal of Financial Economics, 101(2), 449-472. Doi: 10.1016/j.jfineco.2011.03.006

Williams, P., Morton, J. K. ve Christian, B. J. (2020). Enhancing financial literacy in children 5-12 years old using authentic learning within a school market garden programme. Education, 3(13), 1-14.

Doi: 10.1080/03004279.2020.1851741

Yıldırım, A. ve Şimşek, H. (2016). Sosyal bilimlerde nitel araştırma yöntemleri. Ankara: Seçkin Yayıncılık.

Yiğitbaş, Ş., Temeloğlu, E. ve Şimşek, A. (2020). Ortaöğretim çağındaki gençlerde finansal eğitimin finansal okuryazarlık üzerindeki etkisi. IBAD Sosyal Bilimler Dergisi, Milli Mücadele'nin 100. Y1lı Özel Sayıs1, 411-432.

Zhu, A. Y. F., Yu, C. W. M. ve Chou, K. L. (2021). Improving financial literacy in secondary school students: An randomized experiment. Youth \& Society, 53(4), 539-562. Doi: 10.1177/0044118X19851311 